\title{
THE GOVERNMENT SPENDING-REVENUE NEXUS IN CEE COUNTRIES: SOME EVIDENCE FOR ASYMMETRIC EFFECTS
}

\author{
Mesut Karakas, Taner Turan*
}

\begin{abstract}
This paper investigates the government spending-revenue nexus for Croatia, Czechia, Hungary, Poland, Romania and Slovenia by using quarterly data and a nonlinear autoregressive distributed lag (NARDL) approach to cointegration. Our empirical findings support the fiscal synchronization for Slovenia, spend-tax for Czechia, tax-spend for Croatia and Hungary, and institutional separation or fiscal neutrality for Romania and Poland in the long run. Moreover, we find an asymmetric effect for Croatia, Czechia, Hungary and Poland in the long run and for all the countries in the short run. Therefore, our results clearly highlight the importance of asymmetric effects in government spending-revenue nexus. Our findings have some policy implications for these countries, such as providing a better coordination of government spending and revenue decisions and paying attention to the asymmetries.
\end{abstract}

Keywords: spend-tax, tax-spend, fiscal synchronization, asymmetric effects

JEL Classification: E62, H20, H50

\section{Introduction}

The government spending-revenue nexus has been an active research topic since the 1980s. This fact can be linked to the increasing government spending, revenue, budget deficits and public debt levels over time in many countries. This study tries to shed light on some important policy issues, such as how to restrain the government spending, cut the tax rates, reduce the budget deficits and ensure fiscal discipline. Since the stakes are high, it is important to determine whether government spending and revenue are related or not. If they are related, how? If they are not, what are the possible consequences? Does government spending lead to changes in government revenue or the vice versa? Does any asymmetric effect exist? For example, is there a difference in the response of government spending to positive and negative changes in government revenue? It is clear that these questions have important policy implications for fiscal policy decisions.

Although there is no doubt about the importance of the government spending-revenue nexus, only a few studies, such as Mutascu (2016), have examined the issue in the context of CEE countries. Besides, as far as we are aware, except Tiwari and Mutascu (2016)

* Mesut Karakas, Faculty of Business Administration, Gebze Technical University, Turkey (mkarakas@gtu.edu.tr);

Taner Turan, Faculty of Business Administration, Gebze Technical University, Turkey (tturan@gtu.edu.tr). 
for Romania, no study has paid any attention to the asymmetric effects for this group of countries. The present study aims to examine the relationship between the government spending and revenue for Croatia, Czechia, Hungary, Romania, Poland and Slovenia by means of a nonlinear autoregressive distributed lag (NARDL) approach and quarterly data. This approach enables us to make a distinction between the effects of negative and positive changes in the government spending and revenue. In doing so, we are able to test and examine the asymmetric effects. Like many other areas in economics, asymmetric effects relating to the government spending-revenue nexus have been drawing more attention in recent years. Many studies, such as Ewing et al. (2006) and Athanasenas et al. (2014), clearly demonstrate the importance of asymmetric effects in this context. In this study, we present evidence for the existence of asymmetric effects in Croatia, Czechia, Hungary and Poland in the long run and for all the countries in the short run.

We review the literature in Section 2, describe the data sources and unit root tests in Section 3, explain the empirical specification in Section 4, present and discuss empirical findings in Section 5, and finally conclude in Section 6.

\section{Literature Review}

There are four main theoretical approaches trying to explain the somewhat mysterious relationship between government spending and revenue: tax-spend, spend-tax, fiscal synchronization and, finally, the institutional separation or fiscal neutrality hypothesis.

The first one, called tax-spend in the literature, is supported by the leading monetarist Friedman (1978) and public choice economists such as Buchanan and Wagner (1977). According to this approach, there is a causal relationship running from taxing to spending. Friedman (1978) asserts that the government spends more if it has more revenues. In other words, more revenue will result in more spending. Therefore, a cut on tax or revenue leads to a decrease in government spending. Barro (2003) and Becker et al. (2004) also support this proposition. This argument also implies that raising tax rates is not an effective way to deal with government budget deficits because an increase in tax revenues causes the government to spend more with no improvement in the budget balance. In contrast to Friedman's argument, we should note that, in a novel study, Romer and Romer (2007) find that tax cuts do not restrain the government spending in the case of the US; rather, they may even increase the spending. Although Buchanan and Wagner $(1977,1978)$ also claim that the tax rate is the driving force, they predict a different relationship. They highlight the importance of fiscal illusion and make a distinction between direct and indirect taxes to finance government spending. In this view, voters underestimate the real costs of government services due to fiscal illusion. A cut in tax revenues leads to more, not less government spending in this case because of the fiscal illusion the voters arguably suffer from. In a similar way, an increase in direct tax revenues makes voters perceive the real costs of government-provided services better, ending up with less government spending. Many studies empirically confirm the tax-spend hypothesis, including Ram (1988) for the US, Park (1998) for Korea, Hatemi-J and Shukur (1999) for Finland, Narayan and Narayan (2006) for a group of developing countries, Payne et al. (2008) for Turkey and Apergis et al. (2012) for Greece. 
The second approach, spend-tax, argues that the government makes spending decisions first and then adjusts the tax or revenue level accordingly. This argument is brought up by many economists, such as Peacock and Wiseman (1979), who also predict that a temporary increase in government spending, for example arising from a crisis, leads to a permanent or lasting increase in government revenues. The famous tax smoothing hypothesis of Barro (1979) is also consistent with this view. Tax smoothing requires the government to adjust tax rates optimally as a response to a change in government spending. Moreover, taking government spending as exogenous is a standard assumption in the optimal fiscal policy literature. Some studies lend evidence for the spend-tax hypothesis, among them are Ram (1988) for the US state and local governments, Hondroyiannis and Papapetrou (1996) for Greece, Saunoris and Payne (2010) for the UK and Bröthaler and Getzner (2015) for Austria.

Some economists, such as Musgrave (1966) and Meltzer and Richard (1981), suggest that government spending and revenue decisions are jointly made and interdependent, implying the existence of fiscal synchronization. According to this hypothesis, government spending and revenue decisions are based on marginal analysis. This approach posits a twoway relationship between government spending and revenue. Miller and Russek (1990) for the US, Chang and Chiang (2009) for OECD countries, Aslan and Tasdemir (2009) and Turan and Karakas (2018) for Turkey, Vamvoukas (2012) for the European Monetary Union, Paleologou (2013) for Germany and Sweden and Irandoust (2017) for Sweden support the fiscal synchronization hypothesis.

The fourth explanation comes from Wildavsky (1988), who argues that separate government institutions or entities are responsible for making spending and revenue decisions, implying an independent process and a lack of coordination in this regard. This approach suggests that there is no causal relationship between government spending and revenue according to causality tests or results from analyses in a vector autoregression (VAR) framework. However, one can question to what extent these decisions can be independent of each other. Some studies, such as Hoover and Sheffrin (1992) for the US after late the 1960s, Baghestani and McNown (1994) for the US, Chang et al. (2002) for New Zealand and Thailand, Narayan and Narayan (2006) for a group of developing countries and Owoye and Onafowora (2011) for some OECD countries, report that there is no causal relationship between government spending and revenue.

A few studies have focused on the relationship between the government revenue and spending in CEE countries. Luković and Grbić (2014) for Serbia and Tiwari and Mutascu (2016) for Romania support the spend-tax hypothesis. Moreover, Mutascu (2016) reports a causal relationship running from expenditures (revenues) to revenues (expenditures) in Bulgaria (Czechia, Hungary, and Slovenia), and a two-way (no) causality in Slovakia (Estonia, Latvia, Lithuania, Poland and Romania).

Finally, we should note that in recent years, there has been an increasing number of studies paying attention to the asymmetric effects in the context of the government spending-revenue nexus. Ewing et al. (2006) is the first study that focuses on this issue, highlighting the importance of asymmetric effects. Following Enders and Siklos (2001), they employ the threshold autoregression (TAR) and momentum threshold autoregression (MTAR) approaches to examine the asymmetric effects. On the other hand, in a more recent 
study, Athanasenas et al. (2014) employ the NARDL approach, developed by Shin et al. (2014), to detect the asymmetric effects in this context.

\section{Data and Unit Root Tests}

We use general government spending, revenue and GDP data for Croatia, Czechia, Hungary, Poland, Romania and Slovenia. Our data, obtained from the Eurostat database, cover the period 1999:Q1-2016:Q4 for Slovenia, Czechia, and Hungary, 2002:Q1-2016:Q4 for Croatia and Poland, and 1995:Q1-2016:Q4 for Romania. Government revenue (Rev) and spending data (Spend) are calculated as a percentage of GDP and are seasonally adjusted.

Before carrying out any type of autoregressive distributive lag models, the first step is to check the presence of unit roots in government spending and revenue series, which are calculated as a percentage of GDP, since bounds testing is only appropriate when series are either integrated of the order zero (I(0)), one (I(1)) or a mix of them. Thus, our dataset should be free of any series with integration orders of more than 1. The results of our Augmented Dickey Fuller (ADF) test are presented for levels and first differences in Table 1.

Table 1 | ADF Tests

\begin{tabular}{|c|c|c|c|c|c|c|}
\hline Variable & \multicolumn{3}{|c|}{ Spend } & \multicolumn{3}{|c|}{ ReV } \\
\hline Countries & None & $\begin{array}{c}\text { Intercept } \\
\text { only }\end{array}$ & $\begin{array}{l}\text { Intercept } \\
\text { and trend }\end{array}$ & None & $\begin{array}{c}\text { Intercept } \\
\text { only }\end{array}$ & $\begin{array}{l}\text { Intercept } \\
\text { and trend }\end{array}$ \\
\hline Croatia & 0.186 & -1.822 & $-3.945^{* *}$ & 0.782 & -0.323 & -0.976 \\
\hline Czechia & -0.233 & $-3.110^{* *}$ & -3.140 & 0.295 & $-6.328^{* * *}$ & $-7.353^{* * *}$ \\
\hline Hungary & -0.302 & $-4.414^{* * *}$ & $-4.340 * * *$ & 0.224 & -2.052 & $-5.278^{* * *}$ \\
\hline Poland & -0.986 & -1.021 & -2.137 & -2.365 & -2.667 & -0.267 \\
\hline Romania & -0.002 & -2.339 & -2.229 & -0.096 & $-5.208^{* * *}$ & $-5.557^{* * *}$ \\
\hline Slovenia & -0.194 & $-6.337^{* * *}$ & $-6.867^{* * *}$ & -0.121 & -2.326 & -2.654 \\
\hline Variable & \multicolumn{3}{|c|}{$\Delta$ Spend } & \multicolumn{3}{|c|}{$\Delta R e v$} \\
\hline Countries & None & $\begin{array}{l}\text { Intercept } \\
\text { only }\end{array}$ & $\begin{array}{l}\text { Intercept } \\
\text { and trend }\end{array}$ & None & $\begin{array}{l}\text { Intercept } \\
\text { only }\end{array}$ & $\begin{array}{l}\text { Intercept } \\
\text { and trend }\end{array}$ \\
\hline Croatia & $-11.821^{* * *}$ & $-11.718^{* * *}$ & $-11.723^{* * *}$ & $-3.577^{* * *}$ & $-3.634^{* * *}$ & $-9.550^{* * *}$ \\
\hline Czechia & $-9.453^{* * *}$ & $-9.383^{* * *}$ & $-9.384^{* * *}$ & $-8.038^{* * *}$ & $-7.995^{* * *}$ & $-7.935^{* * *}$ \\
\hline Hungary & $-4.694^{* * *}$ & $-4.645^{* * *}$ & $-5.488^{* * *}$ & $-14.828^{* * *}$ & $-14.734^{* * *}$ & $-14.627^{* * *}$ \\
\hline Poland & $-7.168^{* * *}$ & $-7.240^{* * *}$ & $-7.184^{* * *}$ & $-12.448^{* * *}$ & $-12.339 * * *$ & $-12.539 * * *$ \\
\hline Romania & $-9.620^{* * *}$ & $-9.560^{* * *}$ & $-9.543^{* * *}$ & $-17.050^{* * *}$ & $-16.949 * * *$ & $-16.871^{* * *}$ \\
\hline Slovenia & $-8.620^{* * *}$ & $-8.553^{* * *}$ & $-8.505^{* * *}$ & $-13.498^{* * *}$ & $-13.401^{* * *}$ & $-13.307^{* * *}$ \\
\hline
\end{tabular}

Note: $*^{* *},{ }^{* *}$, and ${ }^{*}$ indicate the significance at $1 \%, 5 \%$ and $10 \%$ levels, respectively.

Source: own computations 
The ADF test results indicate that we reject the presence of unit roots for government spending series in some but not all specifications for Slovenia, Hungary, Czechia and Croatia in levels. The test identifies that government spending series have unit roots in Poland and Romania. For the government revenue, we conclude that there is no unit root in the case of Slovenia, Poland and Croatia. However, we fail to reject the existence of unit roots in Hungary, Czechia and Romania in some specifications. As for the first difference, there is no unit root for all the countries for both government revenue and spending series at even the 1 percent significance level. We also implement Phillips-Perron (PP) unit root tests and obtain similar results but we do not report them due to space considerations. All in all, the results given in Table 1 show that data series for all the countries in first differences have no unit roots, meaning that the maximum order of integration is at most 1 for the revenue and spending series.

\section{Empirical Specification and Method}

In this study, we follow Athanasenas et al. (2014) and employ the NARDL approach to cointegration to examine the relationship between government spending and revenue for CEE countries. Unlike the autoregressive distributed lag (ARDL) model, the NARDL model developed by Shin et al. (2014) decomposes cumulative negative and positive shocks to capture nonlinear effects. Cumulative negative shocks are defined for revenue and spending series as:

$$
\begin{gathered}
\operatorname{Rev}_{t}^{-}=\sum_{i=1}^{t} \Delta \operatorname{Rev}_{i}^{-}=\sum_{i=1}^{t} \min \left(\Delta \operatorname{Rev}_{i}, 0\right) \\
\text { Spend }_{t}^{-}=\sum_{i=1}^{t} \Delta \text { Spend }_{i}^{-}=\sum_{i=1}^{t} \min \left(\Delta \text { Spend }_{i}, 0\right) .
\end{gathered}
$$

Also, cumulative positive shocks are defined for revenue and spending series as:

$$
\begin{gathered}
\operatorname{Rev}_{t}^{+}=\sum_{i=1}^{t} \Delta \operatorname{Rev}_{i}^{+}=\sum_{i=1}^{t} \max \left(\Delta \operatorname{Rev}_{i}, 0\right), \\
\text { Spend }_{t}^{+}=\sum_{i=1}^{t} \Delta \text { Spend }_{i}^{+}=\sum_{i=1}^{t} \max \left(\Delta \text { Spend }_{i}, 0\right) .
\end{gathered}
$$

Shin et al. (2014) use negative and positive shocks to redefine the bounds testing approach of Pesaran et al. (2001) in a nonlinear framework. Using the approach of Shin et al. (2014) and Athanasenas et al. (2014), the NARDL model can be written for revenue and spending as follows:

$$
\begin{aligned}
\Delta \text { Spend }_{t}=\alpha_{0} & +\sum_{j=1}^{k} \beta_{1 j} \Delta \text { Spend }_{t-j}+\sum_{j=0}^{n} \beta_{2 j} \Delta \operatorname{Rev}_{t-j}^{-}+\sum_{j=0}^{q} \beta_{3 j} \Delta \operatorname{Rev}_{t-j}^{+}+ \\
& +\mu_{0} \text { Spend }_{t-1}+\pi^{-} \operatorname{Rev}_{t-1}^{-}+\pi^{+} \operatorname{Rev}_{t-1}^{+}+\varepsilon_{t},
\end{aligned}
$$




$$
\begin{aligned}
\Delta \operatorname{Rev}_{t}=\alpha_{0} & +\sum_{j=1}^{k} \beta_{1 j} \Delta \operatorname{Rev}_{t-j}+\sum_{j=0}^{n} \beta_{2 j} \Delta \text { Spend }_{t-j}^{-}+\sum_{j=0}^{q} \beta_{3 j} \Delta \text { Spend }_{t-j}^{+}+ \\
& +\mu_{0} \operatorname{Rev}_{t-1}+\pi^{-} \text {Spend }_{t-1}^{-}+\pi^{+} \text {Spend }_{t-1}^{+}+\varepsilon_{t},
\end{aligned}
$$

where Rev and Spend stand for government revenue and spending as a percentage of GDP, respectively. We allow for a maximum of 8 lags in our study. Also, the Akaike information criterion is used to determine the optimal lag structure for the NARDL equations.

We implement an F test in our NARDL framework to determine the existence of a longrun relationship between government revenue and spending for each country. To accomplish that, we set the null hypothesis as $H_{0}: \mu_{0}=\pi^{-}=\pi^{+}=0$. If the F statistics show statistical significance compared to the critical values reported in Pesaran et al. (2001), then we conclude that there is a cointegration. In the next step, we estimate short-run and long-run coefficients to identify asymmetries.

\section{Empirical Results}

We report our NARDL results in Table 2 with government spending being the dependent variable. Note that we use all variables as a percentage of GDP and interpret our results based on the ratios. Also, as mentioned, we use the Akaike information criterion to select the optimal lag length for variables in each dynamic asymmetric estimation equation. Actually, the Schwarz criterion is more parsimonious compared to the Akaike criterion in terms of optimal lag length determination. However, the use of a quarterly dataset necessitates inclusion of a sufficiently larger number of lags in our dynamic equations, because past government spendings (revenues) up to 2 years or even earlier may be effective on current government revenues (spendings). Aiming to capture these effects, we use the Akaike information criterion, allowing a maximum of 8 lags in each equation.

To conclude that there exists a cointegration, the estimated F statistics, which we get testing $H_{0}: \mu_{0}=\pi^{-}=\pi^{+}=0$ against $H_{1}: \mu_{0} \neq \pi^{-} \neq \pi^{+} \neq 0$, must exceed the critical values given in Pesaran et al. (2001). We call this test simply an $\mathrm{F}_{\mathrm{PSS}}$ test, emphasizing the fact that the critical values are from the seminal paper of Pesaran et al. (2001). According to the $\mathrm{F}_{\mathrm{PSS}}$ test results given in Table 3 , we fail to reject $H_{0}$ and conclude that there exists no cointegration in the cases of Croatia, Czechia, Hungary and Slovenia. However, the null hypothesis is rejected for Poland and Romania, lending evidence for the validity of cointegration. Since we find a cointegration between government spending and revenue for these four countries, we can discuss the related NARDL results. 
Table 2 | Dynamic Asymmetric Estimation Equations for Spending

\begin{tabular}{|c|c|c|c|c|c|c|}
\hline Countries & Croatia & Czechia & Hungary & Poland & Romania & Slovenia \\
\hline Variable & Coef. & Coef. & Coef. & Coef. & Coef. & Coef. \\
\hline Constant & $97.630^{* * *}$ & $18.288^{* * *}$ & $23.144^{* * *}$ & $6.710^{* *}$ & 6.481 & $38.992^{* * *}$ \\
\hline$\Delta$ Spend $_{t-1}$ & $0.843^{* *}$ & $-0.290^{* *}$ & 0.080 & 0.155 & $-0.382^{* * *}$ & -0.068 \\
\hline$\Delta$ Spend $_{t-2}$ & $0.735^{* *}$ & - & $0.258^{* *}$ & - & $-0.341^{* *}$ & - \\
\hline$\Delta$ Spend $_{t-3}$ & $0.660^{* *}$ & - & $0.440^{* * *}$ & - & $-0.272^{* *}$ & - \\
\hline$\Delta$ Spend $_{t-4}$ & $0.606^{* *}$ & - & - & - & 0.180 & - \\
\hline$\Delta$ Spend $_{t-5}$ & $0.537^{* *}$ & - & - & - & 0.181 & - \\
\hline$\Delta$ Spend $_{t-6}$ & $0.371^{*}$ & - & - & - & $0.243^{* * *}$ & - \\
\hline$\Delta$ Spend $_{t-7}$ & $0.564^{* * *}$ & - & - & - & $0.164^{* * *}$ & - \\
\hline$\Delta$ Spend $_{t-8}$ & $0.327^{* *}$ & - & - & - & - & - \\
\hline$\Delta \operatorname{Rev}_{t}^{-}$ & $0.757^{*}$ & 0.214 & 0.040 & 0.037 & 0.435 & $3.679 * * *$ \\
\hline$\Delta \operatorname{Rev}_{t-1}^{-}$ & 0.423 & $0.602^{* *}$ & $0.313^{* *}$ & -0.086 & - & - \\
\hline$\Delta \operatorname{Rev}_{t-2}^{-}$ & -0.427 & - & $0.274^{* *}$ & 0.012 & - & - \\
\hline$\Delta \operatorname{Rev}_{t-3}^{-}$ & -0.542 & - & - & $-0.275^{* * *}$ & - & - \\
\hline$\Delta \operatorname{Rev}_{t-4}^{-}$ & 0.586 & - & - & -0.115 & - & - \\
\hline$\Delta \operatorname{Rev}_{t-5}^{-}$ & - & - & - & $-0.231^{* * *}$ & - & - \\
\hline$\Delta \operatorname{Rev}_{t}^{+}$ & 0.045 & $0.966^{* * *}$ & -0.109 & $0.471^{* * *}$ & $1.122^{* * *}$ & 0.060 \\
\hline$\Delta \operatorname{Rev}_{t-1}^{+}$ & $-1.155^{* * *}$ & -0.051 & - & - & $0.561^{*}$ & $3.852^{* * * *}$ \\
\hline$\Delta \operatorname{Rev}_{t-2}^{+}$ & $-1.105^{* * *}$ & $0.738^{* * *}$ & - & - & $0.578^{* *}$ & - \\
\hline$\Delta \operatorname{Rev}_{t-3}^{+}$ & $-1.397^{* * *}$ & - & - & - & - & - \\
\hline$\Delta \operatorname{Rev}_{t-4}^{+}$ & $-1.270^{* * *}$ & - & - & - & - & - \\
\hline$\Delta \operatorname{Rev}_{t-5}^{+}$ & $-1.480^{* * *}$ & - & - & - & - & - \\
\hline$\Delta \operatorname{Rev}_{t-6}^{+}$ & $-1.356^{* * *}$ & - & - & - & - & - \\
\hline$\Delta \operatorname{Rev}_{t-7}^{+}$ & $-1.000^{* * *}$ & - & - & - & - & - \\
\hline Spend $_{t-1}$ & $-2.039^{* * *}$ & $-0.443^{* * *}$ & $-0.468^{* * *}$ & $-0.163^{* * *}$ & $-0.215^{* *}$ & $-0.806^{* * *}$ \\
\hline $\operatorname{Rev}_{t-1}^{-}$ & $0.317^{* *}$ & 0.095 & $-0.235^{* *}$ & 0.068 & $0.366^{*}$ & $1.674^{*}$ \\
\hline $\operatorname{Rev}_{t-1}^{+}$ & $0.592^{* * *}$ & 0.086 & $-0.183^{* *}$ & 0.063 & $0.367^{*}$ & $1.733^{* *}$ \\
\hline
\end{tabular}

Notes: Coef. is an abbreviation for coefficient. ${ }^{* *},{ }^{* *}$, and ${ }^{*}$ indicate the significance at $1 \%, 5 \%$ and $10 \%$ levels, respectively.

Source: own computations 
It is a necessity to normalize the long-run coefficients on $\operatorname{Rev}_{t-1}^{-}$and $\operatorname{Rev}_{t-1}^{+}$to evaluate the results of long-run adjustment. We first normalize the negative long-run effect as $\pi^{-} / \mu_{0}$ and the positive long-run effect as $\pi^{+} / \mu_{0}$. Then, we test whether the normalized coefficients are significantly different from zero. We call the test for the negative long-run effect an $\mathrm{L}^{-}$and the test for the positive long-run effect an $\mathrm{L}^{+}$. It can be seen in Table 3 that the coefficients on negative or positive changes in government revenue are significantly positive for Croatia and Slovenia in the long run. This means that a negative (positive) change in government revenue leads to a reduction (increase) in government spending. Interestingly, a negative (positive) change in government revenue results in an increase (decline) in government spending in Hungary. This result appears to be consistent with the predictions of public choice economists discussed in section 2. In the next step, we check whether long-run asymmetry exists or not. To accomplish this, we perform a Wald test for $H_{0}: \pi^{-} / \mu_{0}$ against $H_{1}: \pi^{-} / \mu_{0} \neq \pi^{+} / \mu_{0}$. Our long-run asymmetry test is denoted as $\mathrm{W}_{\mathrm{LR}}$. We reject $H_{0}$ for the case of Croatia and Hungary, concluding that there exists an asymmetric effect in the long run. It is determined that government spending changes more in response to a positive change in government revenue compared to a negative change in Croatia. We also check the shortrun negative effect via a test on $H_{0}: \sum_{j=1}^{n} \beta_{3 j}=0$ against $H_{0}: \sum_{j=1}^{n} \beta_{2 j} \neq 0$ and the shortrun positive effect via a test on $H_{0}: \sum_{j=1}^{q} \beta_{3 j}=0$ against $H_{0}: \sum_{j=1}^{q} \beta_{3 j} \neq 0$. These tests are called $\mathrm{S}^{-}$and $\mathrm{S}^{+}$and are shown in Table 3 . Rejection of null hypotheses enables us to conclude that negative changes in government revenue have a significant effect in Czechia, Hungary, Poland and Slovenia, whereas positive changes exert a significant effect in all the countries except Hungary. We also try to determine an asymmetry in the short run by testing $H_{0}: \sum_{j=1}^{n} \beta_{2 j}=\sum_{j=1}^{q} \beta_{3 j}$ against $H_{1}: \sum_{j=1}^{n} \beta_{2 j} \neq \sum_{j=1}^{q} \beta_{3 j}$. This test statistic is shown as $\mathrm{W}_{\mathrm{SR}}$ in Table 3. Rejection of the null hypothesis lends evidence for the existence of shortrun asymmetry. Our results indicate that there exists a negative short-run asymmetry for all the countries, with the exception of Slovenia. We also report diagnostic tests, which suggest that there are no serial correlation, heteroscedasticity and model misspecification problems in our estimations. 
Table 3 | Tests for Dynamic Asymmetric Estimation Equations for Spending

\begin{tabular}{|l|c|c|c|c|c|c|}
\hline Countries & Croatia & Czechia & Hungary & Poland & Romania & Slovenia \\
\hline $\boldsymbol{F}_{P S S}$ & $10.965^{* * *}$ & $4.772^{*}$ & $9.298^{* * *}$ & 3.472 & 2.238 & $8.324^{* * *}$ \\
\hline $\boldsymbol{L -}$ & $2.289^{* *}$ & 0.372 & $-2.328^{* *}$ & 0.930 & 1.502 & $2.065^{* *}$ \\
\hline $\boldsymbol{L}+$ & $4.265^{* * *}$ & 0.364 & $-2.134^{* *}$ & 0.757 & 1.534 & $2.334^{* *}$ \\
\hline $\boldsymbol{S}-$ & 0.578 & $2.274^{* *}$ & $3.085^{* * *}$ & $-2.500^{* *}$ & 1.283 & $2.676^{* * *}$ \\
\hline $\boldsymbol{S}+$ & $-5.006^{* * *}$ & $3.806^{* * *}$ & -1.009 & $4.093^{* * *}$ & $3.558^{* * *}$ & $2.036^{* *}$ \\
\hline $\boldsymbol{W}_{\text {LR }}$ & $-8.334^{* * *}$ & 0.372 & $-2.762^{* * *}$ & 0.342 & -0.069 & -0.557 \\
\hline $\boldsymbol{W}_{S R}$ & $3.970^{* * *}$ & $-2.474^{* *}$ & $3.023^{* * *}$ & $-3.671^{* * *}$ & $-2.496^{* *}$ & -0.092 \\
\hline $\boldsymbol{R}^{2}$ & 0.820 & 0.792 & 0.401 & 0.509 & 0.544 & 0.574 \\
\hline $\boldsymbol{a d j} \boldsymbol{R}^{2}$ & 0.655 & 0.760 & 0.296 & 0.381 & 0.446 & 0.526 \\
\hline LM Test Prob. & {$[0.653]$} & {$[0.597]$} & {$[0.720]$} & {$[0.440]$} & {$[0.457]$} & {$[0.293]$} \\
\hline ARCH Test Prob. & {$[0.206]$} & {$[0.653]$} & {$[0.539]$} & {$[0.274]$} & {$[0.861]$} & {$[0.888]$} \\
\hline Reset Test Prob. & {$[0.347]$} & {$[0.663]$} & {$[0.609]$} & {$[0.418]$} & {$[0.401]$} & {$[0.200]$} \\
\hline
\end{tabular}

Notes: ${ }^{* * *},{ }^{* *}$, and ${ }^{*}$ indicate the significance at $1 \%, 5 \%$ and $10 \%$ levels, respectively. Numbers in square brackets are $p$-values.

Source: own computations

We report the NARDL results with government revenue being the dependent variable in Table 4. 
Table 4 | Dynamic Asymmetric Estimation Equations for Revenue

\begin{tabular}{|c|c|c|c|c|c|c|}
\hline Countries & Croatia & Czechia & Hungary & Poland & Romania & Slovenia \\
\hline Variable & Coef. & Coef. & Coef. & Coef. & Coef. & Coef. \\
\hline Constant & 15.542 & $21.916^{* * *}$ & $16.582^{* * *}$ & $17.474^{* *}$ & $15.827^{* * *}$ & $19.302^{* * *}$ \\
\hline$\Delta \operatorname{Rev}_{t-1}$ & 0.215 & $-0.389^{* *}$ & $-0.276^{* *}$ & -0.174 & -0.183 & $-0.280^{* *}$ \\
\hline$\Delta \operatorname{Rev}_{t-2}$ & -0.103 & $-0.247^{* *}$ & - & $-0.374^{*}$ & $0.233^{*}$ & - \\
\hline$\Delta \operatorname{Rev}_{t-3}$ & 0.097 & $-0.154^{*}$ & - & 0.100 & $0.257^{* *}$ & - \\
\hline$\Delta \operatorname{Rev}_{t-4}$ & -0.462 & - & - & -0.141 & -0.034 & - \\
\hline$\Delta \operatorname{Rev}_{t-5}$ & 0.327 & - & - & $0.395^{* *}$ & 0.115 & - \\
\hline$\Delta \operatorname{Rev}_{t-6}$ & -0.120 & - & - & 0.125 & 0.191 & - \\
\hline$\Delta \operatorname{Rev}_{t-7}$ & 0.160 & - & - & $0.325^{* *}$ & $0.231^{* *}$ & - \\
\hline$\Delta \operatorname{Rev}_{t-8}$ & $-0.490^{* *}$ & - & - & - & - & - \\
\hline$\Delta$ Spend $_{t}^{-}$ & -0.0002 & -0.262 & $0.807^{* *}$ & 0.613 & $0.417^{* * *}$ & $0.165^{* * *}$ \\
\hline$\Delta$ Spend $_{t-1}^{-}$ & 0.234 & - & - & $0.963^{* *}$ & - & - \\
\hline$\Delta$ Spend $_{t-2}^{-}$ & $0.782^{* * * *}$ & - & - & -0.198 & - & - \\
\hline$\Delta$ Spend $_{t-3}^{-}$ & -0.018 & - & - & $1.245^{* * *}$ & - & - \\
\hline$\Delta$ Spend $_{t-4}^{-}$ & $0.446^{*}$ & - & - & 0.232 & - & - \\
\hline$\Delta$ Spend $_{t-5}^{-}$ & 0.329 & - & - & 0.599 & - & - \\
\hline$\Delta$ Spend $_{t-6}^{-}$ & -0.376 & - & - & 0.545 & - & - \\
\hline$\Delta$ Spend $_{t-7}^{-}$ & $0.560^{* *}$ & - & - & 0.313 & - & - \\
\hline$\Delta$ Spend $_{t-8}^{-}$ & 0.380 & - & - & -0.462 & - & - \\
\hline$\Delta$ Spend $_{t}^{+}$ & 0.277 & $0.728^{* * *}$ & -0.547 & $1.281^{* *}$ & 0.123 & 0.025 \\
\hline$\Delta$ Spend $_{t-1}^{+}$ & -0.444 & $-0.513^{* *}$ & - & $-1.883^{* * *}$ & $0.297^{* *}$ & - \\
\hline$\Delta$ Spend $_{t-2}^{+}$ & $-0.754^{*}$ & $-0.377^{* * *}$ & - & 0.856 & - & - \\
\hline$\Delta$ Spend $_{t-3}^{+}$ & -0.017 & - & - & -0.711 & - & - \\
\hline$\Delta$ Spend $_{t-4}^{+}$ & 0.027 & - & - & -0.425 & - & - \\
\hline$\Delta$ Spend $_{t-5}^{+}$ & -0.134 & - & - & $-1.645^{* * *}$ & - & - \\
\hline$\Delta$ Spend $_{t-6}^{+}$ & 0.542 & - & - & -0.865 & - & - \\
\hline$\Delta$ Spend $_{t-7}^{+}$ & -0.471 & - & - & - & - & - \\
\hline $\operatorname{Rev}_{t-1}$ & $-0.367^{*}$ & $-0.605^{* * *}$ & $-0.380^{* * *}$ & $-0.377^{* *}$ & $-0.489^{* * *}$ & $-0.449 * * *$ \\
\hline Spend $_{t-1}^{-}$ & -0.333 & $0.280^{* *}$ & 0.067 & $0.229^{*}$ & 0.009 & $0.136^{* * *}$ \\
\hline Spend $_{t-1}^{+}$ & -0.236 & $0.318^{* *}$ & 0.134 & 0.157 & 0.014 & $0.142^{* * *}$ \\
\hline
\end{tabular}

Notes: Coef. is an abbreviation for coefficient. ${ }^{* *},{ }^{* *}$, and ${ }^{*}$ indicate the significance at $1 \%, 5 \%$ and $10 \%$ levels, respectively.

Source: own computations 
The $\mathrm{F}_{\mathrm{PSS}}$ test results given in Table 5 show that there exists a cointegration between the government revenue and spending for Czechia, Poland, Romania and Slovenia but not for Croatia and Hungary.

Table 5 | Tests for Dynamic Asymmetric Estimation Equations for Revenue

\begin{tabular}{|l|c|c|c|c|c|c|}
\hline Countries & Croatia & Czechia & Hungary & Poland & Romania & Slovenia \\
\hline $\boldsymbol{F}_{\text {PSS }}$ & 2.543 & $4.775^{*}$ & 3.746 & $5.234^{* *}$ & $5.132^{* *}$ & $4.494^{*}$ \\
\hline $\boldsymbol{L}^{-}$ & -0.916 & $1.703^{*}$ & 0.428 & 1.208 & 0.164 & $2.568^{* *}$ \\
\hline $\boldsymbol{L}^{+}$ & -0.822 & $1.962^{*}$ & 0.880 & 0.745 & 0.281 & $2.777^{* * *}$ \\
\hline $\boldsymbol{S}^{-}$ & $2.068^{*}$ & -1.076 & $2.162^{* *}$ & $2.810^{* * *}$ & $3.169^{* * *}$ & $3.235^{* * *}$ \\
\hline $\boldsymbol{S}^{+}$ & -1.107 & -0.622 & -1.614 & $-2.402^{* *}$ & $3.813^{* * *}$ & 1.212 \\
\hline $\boldsymbol{W}_{\text {LR }}$ & -1.174 & $-3.388^{* * *}$ & $-3.313^{* * *}$ & $1.822^{*}$ & -0.987 & -1.141 \\
\hline $\boldsymbol{W}_{S R}$ & $2.984^{* * *}$ & -0.411 & $2.251^{* *}$ & $3.357^{* * *}$ & -0.021 & $2.439^{* *}$ \\
\hline $\boldsymbol{R}^{2}$ & 0.809 & 0.810 & 0.422 & 0.873 & 0.586 & 0.382 \\
\hline $\boldsymbol{a d j R ^ { 2 }}$ & 0.567 & 0.777 & 0.367 & 0.735 & 0.505 & 0.323 \\
\hline $\begin{array}{l}\text { LM Test } \\
\text { Prob. }\end{array}$ & {$[0.999]$} & {$[0.241]$} & {$[0.400]$} & {$[0.779]$} & {$[0.574]$} & {$[0.349]$} \\
\hline $\begin{array}{l}\text { ARCH Test } \\
\text { Prob. }\end{array}$ & {$[0.752]$} & {$[0.912]$} & {$[0.931]$} & {$[0.306]$} & {$[0.896]$} & {$[0.699]$} \\
\hline $\begin{array}{l}\text { Reset Test } \\
\text { Prob. }\end{array}$ & {$[0.989]$} & {$[0.004]$} & {$[0.268]$} & {$[0.610]$} & {$[0.083]$} & {$[0.203]$} \\
\hline
\end{tabular}

Notes: ${ }^{* * *},{ }^{* *}$, and ${ }^{*}$ indicate the significance at $1 \%, 5 \%$ and $10 \%$ levels, respectively. Numbers in square brackets are $p$-values.

Source: own computations

A negative (positive) change in government spending leads to a significant decline (increase) in government revenue in Czechia and Slovenia in the long run. We conclude that there is an asymmetric effect of changes in government spending on the revenue in Czechia and Poland in the long run. In the short run, we find that a negative change in the government spending significantly affects the government revenue for Poland, Romania and Slovenia, while the coefficients on positive changes are significant in the cases of Poland and Romania. An asymmetric effect exists in Slovenia and Poland in the short run. Our diagnostic tests show that there are no serial correlation, heteroscedasticity and model misspecification problems at the 5 percent significance level except Czechia. In the case of Czechia, the result of the reset test points to a model specification problem. Since our analysis focuses on the long-run and short-run relationships between government revenue and spending as a percentage of GDP, we do not correct the functional form of our model 
further and rely on the existing findings. Actually, any attempt via adding second and third powers of independent variables to correct the functional form of the equation for Czechia makes us diverge from the model structure that we use in the NARDL approach.

Finally, our results suggest that there is evidence for the fiscal synchronization hypothesis in Slovenia, spend-tax in Czechia and tax-spend in Croatia and Hungary. Since we do not find any significant effect of government revenue (spending) on the government spending (revenue) for Romania and Poland in the long run, we conclude that government spending and revenue are independent of each other, supporting the institutional separation view in these two countries. This last finding is consistent with that of Mutascu (2016), who suggests that there is no causal relationship between the related variables in Romania and Poland.

\section{Conclusion}

This paper investigates the relationship between government spending and revenue, both as a percentage of GDP, for Croatia, Czechia, Hungary, Poland, Romania and Slovenia by using quarterly data and the NARDL approach to cointegration. Our results indicate that government revenue has a significant effect on government spending for Croatia, Slovenia and Hungary in the long run. It is also determined that government spending exerts a significant impact on government revenue for Slovenia and Czechia. On the other hand, there is no significant effect of government revenue (spending) on government spending (revenue) for Romania and Poland in the long run. Therefore, we conclude that our findings support fiscal synchronization hypothesis in Slovenia, spend-tax in Czechia, tax-spend in Croatia and Hungary, and institutional separation in Romania and Poland in the long run. Moreover, we find an asymmetric effect for Croatia, Czechia, Hungary and Poland in the long run and for all the countries in the short run. Therefore, our results clearly highlight the importance of the asymmetric effect in the government spending-revenue nexus.

As for our policy proposal, we stand up for better coordination between government spending and revenue decisions. Fiscal synchronization is crucial for a good fiscal policy but one-sided approaches such as spend-tax and tax-spend also play important roles in policy formulation. However, none of these mechanisms exists for Romania and Poland. A lack of a long-run relationship between government revenue and spending is prone to create some difficulties for fiscal policy and discipline in these countries. Moreover, the existence of asymmetric long-run effects poses problems for budget balances by impairing the adjustment mechanisms. Our results indicate a risk of such a problem for Croatia, Czechia, Hungary and Poland. It is better for these countries to take precautionary steps towards providing a budget balance in the future. We should note that the recent global crisis has shown the importance of fiscal policy once again. Governments with a sound fiscal stance are better-suited to deal with shocks by implementing countercyclical policies. Besides, fiscal policy and stance matters not only for stabilization purposes but also for efficient allocation of resources among alternative means and external balance as well. Therefore, it would be helpful if these countries paid more attention to the government spending- 
revenue nexus. In this context, it would be worth considering enactment and implementation of some form of effective national fiscal policy rules to better coordinate government spending and revenue decisions. A well-designed fiscal rule would play an important role in avoiding undesired outcomes arising from suboptimal and uncoordinated fiscal policy decisions.

\section{References}

Apergis, N., Payne, J. E., Saunoris, J. W. (2012). Tax-spend Nexus in Greece: are there Asymmetries? Journal of Economic Studies, 39(3), 327-336, https://doi. org/10.1108\%2F01443581211245900

Aslan, M., Tasdemir, M. (2009). Is Fiscal Synchronization Hypothesis Relevant for Turkey? Evidence from Cointegration and Causality Tests with Endogenous Structural Breaks. Journal of Money, Investment and Banking, 12, 14-25.

Athanasenas, A., Katrakilidis, C., Trachanas, E. (2014). Government Spending and Revenues in the Greek Economy: Evidence from Nonlinear Cointegration. Empirica, 41, 365-2, https://doi.org/10.1007\%2Fs10663-013-9221-3

Baghestani, H., McNown, R. (1994). Do Revenues or Expenditures Respond to Budgetary Disequilibria? Southern Economic Journal, 60, 311-322, https://doi. org/10.2307\%2F1059979

Barro, R. J. (1979). On the Determination of the Public Debt. Journal of Political Economy, 81, 940-71.

Barro, R. J. (2003). There is a lot to like Bush's Tax Plan. Business Week, February 24.

Becker, G., Lazear, E. P., Murphy, K. M. (2004). The Double Benefit of Tax Cuts. Hoover Digest, 1, 128-131.

Bröthaler, J., Getzner, M. (2015). The Tax-Spend Debate and Budgetary Policy in Austria. International Advances in Economic Research, 21(3), 299-315, https://doi. org/10.1007\%2Fs11294-015-9532-1

Buchanan, J., Wagner, R. (1977). Democracy in Deficit. New York: Academic Press.

Buchanan, J., Wagner, R. (1978). Dialogues Concerning Fiscal Religion. Journal of Monetary Economics, 4(3), 627-636, https://doi.org/10.1016\%2F0304-3932\%2878\%2990056-9

Chang, T., Chiang, G. (2009). Revisiting the Government Revenue-Expenditure Nexus: Evidence from 15 OECD Countries Based On the Panel Data Approach. Czech Journal of Economics and Finance, 59(2), 165-172.

Chang, T., Liu, W. R., Caudill, S. B. (2002). Tax-and-spend, spend-and-tax, or Fiscal Synchronization: New Evidence for ten Countries. Applied Economics, 34, 1553-561, https://doi.org/10.1080\%2F00036840110103265

Enders, W., Siklos, P. (2001). Cointegration and Threshold Adjustment. Journal of Business and Economic Statistics, 19, 166-176, https://doi.org/10.2139\%2Fssrn.62008

Ewing, B. T., Payne, J. E., Thompson, M. A., Al-Zoubi, O. M. (2006). Government Expenditures and Revenues: Evidence from Asymmetric Modeling. Southern Economic Journal, 73(1), 190-200, https://doi.org/10.2307\%2F20111882

Friedman, M. (1978). The Limitations of Tax Limitation. Policy Review, 7-14.

Hatemi-J, A., Shukur, G. (1999). The Causal Nexus of Government Spending and Revenue in Finland: a Bootstrap Approach. Applied Economics Letters, 6(10), 641-644, https://doi. org/10.1080\%2F135048599352411 
Hondroyiannis, G., Papapetrou, E. (1996). An Examination of the Causal Relationship between Government Spending and Revenue: a Cointegration Analysis. Public Choice, 89, 363-74, https://doi.org/10.1007\%2Fbf00159364

Hoover, K. D., Sheffrin, S. M. (1992). Causation, Spending, and Taxes: Sand in the Sandbox or Tax Collector for the Welfare State? The American Economic Review, 82(1), 225-248.

Irandoust, M. (2017). Government Spending and Revenues in Sweden 1722-2011:

Evidence from Hidden Cointegration. Empirica, 1-15, https://doi. org/10.1007\%2Fs10663-017-9375-5

Luković, S., Grbić, M. (2014). The Causal Relationship between Government Revenue and Expenditure in Serbia. Economic Themes, 52(2), 127-138, https://doi. org/10.1515\%2Fethemes-2014-0009

Meltzer, A. H., Richard, S. F. (1981). A Rational Theory of the Size of Government. Journal of Political Economy, 89, 914-927, https://doi.org/10.1086\%2F261013

Miller, S. M., Russek, F. S. (1990). Co-Integration and Error-Correction Models: The Temporal Causality between Government Taxes and Spending. Southern Economic Journal, 57(1), 221-229, https://doi.org/10.2307\%2F1060491

Musgrave, R. (1966). Principles of Budget Determination, in Cameron, H., Henderson, W., ed., Public Finance: Selected Readings. New York: Random House, pp. 15-27.

Mutascu, M. (2016). Government Revenues and Expenditures in the East European Economies: A Bootstrap Panel Granger Causality Approach. Eastern European Economics, 54(6), 489-502, https://doi.org/10.1080\%2F00128775.2016.1204237

Narayan, P. K., Narayan, S. (2006). Government Revenue and Government Expenditure Nexus: Evidence from Developing Countries. Applied Economics, 38(3), 285-291, https://doi. org/10.1080\%2F00036840500369209

Owoye, O., Onafowora, O. A. (2011). The Relationship between Tax Revenues and Government Expenditures in European Union and Non-European Union OECD Countries. Public Finance Review, 39(3), 429-461, https://doi.org/10.1177\%2F1091142110386211

Paleologou, S-M. (2013). Asymmetries in the Revenue-Expenditure Nexus: A Tale of Three Countries. Economic Modelling, 30, 52-60, https://doi.org/10.1016\%2Fj. econmod.2012.09.022

Park, W. K. (1998). Granger Causality between Government Revenues and Expenditures in Korea. Journal of Economic Development, 23(1), 145-155.

Payne, J. E., Mohammadi, H., Cak, M. (2008). Turkish Budget Deficit Sustainability and the Revenue-Expenditure Nexus. Applied Economics, 40(7), 823-830, https://doi. org/10.1080/00036840600749904

Peacock, A., Wiseman, J. (1979). Approaches to the Analysis of Government Expenditure Growth. Public Finance Review, 7, 3-23, https://doi.org/10.1177\%2F109114217900700101

Pesaran, M. H., Shin, Y., Smith, R. J. (2001). Bounds Testing Approaches to the Analysis of Level Relationships. Journal of Applied Econometrics, 16, 289-326, https://doi. org/10.1002\%2Fjae.616

Ram, R. (1988). Additional Evidence on Causality between Government Revenue and Government Expenditure. Southern Economic Journal, 54(3), 763-769, https://doi. org/10.2307\%2F1059018

Romer, C. D., Romer, D. H. (2007). Do Tax Cuts Starve The Beast? The Effect of Tax Changes on Government Spending. NBER. Working Paper No. 13548, https://doi. org $/ 10.3386 \% 2 \mathrm{Fw} 13548$ 
Saunoris, J. W., Payne, J. E. (2010). Tax more or spend less? Asymmetries in the UK Revenueexpenditure Nexus. Journal of Policy Modeling, 32, 478-487, https://doi.org/10.1016\%2Fj. jpolmod.2010.05.012

Shin, Y., Yu, B., Greenwood-Nimmo, N. (2014). Modelling Asymmetric Cointegration and Dynamic Multipliers in a Nonlinear ARDL Framework, in Sickels, R., Horrace, W., ed., Festschrift in Honor of Peter Schmidt: Econometric Methods and Applications. Springer, pp. 281-314.

Tiwari, A. K., Mutascu, M. (2016). The Revenues-spending Nexus in Romania: a TAR and MTAR Approach. Economic Research-Ekonomska Istraživanja, 29(1), 735-745, https://doi.org/ 10.1080\%2F1331677x.2016.1197549

Turan, T., Karakas, M. (2018). The Relationship between Government Spending and Revenue: Nonlinear Bounds Testing Approach (NARDL). Sosyoekonomi, 26(30), 33-48, https://doi. org/10.17233/sosyoekonomi.2018.02.02.

Vamvoukas, G. A. (2012). Panel Data Modelling and the Tax-spend Controversy in the Euro Zone. Applied Economics, 44(31), 4073-4085, https://doi.org/10.1080 \%2F00036846.2011.587777

Wildavsky, A. (1988). The New Politics of the Budgetary Process. Glenview, IL: Scott, Foresman. 